\title{
IbM PENGOLAHAN BUAH NAGA SEBAGAI UPAYA MENINGKATKAN NILAI TAMBAH DAN PENGENDALIAN HARGA BUAH NAGA DI KABUPATEN TANAH LAUT
}

\author{
M. Ilmi Hidayat, Inda Ilma Ifada, dan Gusti Khairu Ni’mah \\ Fakultas Petanian, Universitas Islam Kalimantan MAB
}

\begin{abstract}
ABSTRAK
Tujuan dari kegiatan Pengabdian Masyarakat ini adalah untuk :1) Meningkatkan pengetahuan dan ketrampilan masyarakat dalam mengolahan hasil buah naga dan manajemen usaha dalam rangka meningkatkan nilai tambah dari budidaya buah naga, 2) diharapkan mampu menyerap hasil budidaya buah naga yang ada di daerah tersebut, 3) membuka peluang usaha produksi pengolahan buah naga menjadi produk yang dapat dipasarkan dan sekaligus dapat dijadikan salah satu produk unggulan Kabupaten Tanah Laut. Metode kegiatan yang digunakan adalah ceramah, demonstrasi, dan pelatihan. Evaluasi kegiatan pengabdian masyarakat dilakukan pada aspek input, proses, produk, dan kepuasan peserta. Adapun peserta kegiatan IbM ini adalah ibu-ibu PKK, Desa Kunyit dan Tirta Jaya, Kabupaten Tanah Laut. Sedangkan waktu pelaksanaannya yaitu mulai bulan Juli sampai Nopember 2017. Hasil kegiatan pengabdian masyarakat menunjukkan bahwa : 1) Buah naga dapat dibuat menjadi berbagai macam produk olahan yaitu aneka kudapan buah naga, sari buah naga, stik buah naga, selai buah naga, dan ice crem buah naga; 3) berdasarkan tingkat penerimaan konsumen produk olahan buah naga berkisar dari suka sampai sangat suka untuk warna dan ai suka untuk rasa, aroma dan keseluruhan; 4) pengabdian masyarakat ini, mampu memberdayakan, memotivasi, dan mendorong jiwa kewirausahaan para peserta.
\end{abstract}

Kata Kunci : Buah Naga, Nilai Tambah, Kabupaten Tanah Laut

\section{PENDAHULUAN}

Berdasarkan hasil analisis situasi di Kalimantan Selatan buah naga mulai dibudidayakan tanaman sejak tahun 2007 terutama buah naga merah. Tanaman buah naga sebelumnya kurang begitu dikenal, tetapi karena cita rasanya yang manis dan segar, apalagi setelah masyarakat mengetahui manfaatnya bagi kesehatan yaitu mampu menyeimbangkan kadar gula darah, mencegah penyakit diabetes dan kanker usus serta mampu menurunkan kadar kolesterol di dalam tubuh, trend budidaya buah naga meningkat seiring dengan meningkatnya permintaan. Hal tersebut ditunjang pula dengan teknis budidaya buah naga yang mudah dikembangkan pada 
kondisi tanah dan ketinggian lokasi apapun, namun tanaman ini cukup rakus akan unsur hara, sehingga apabila tanah mengandung pupuk yang bagus, maka pertumbuhannya akan baik (Kristanto, 2014).

Pengembangan budidaya tanaman Buah naga diprioritaskan di Kabupaten Tanah Laut mulai Tahun 2007. Pertama kali harga buah naga di tingkat petani yaitu tahun 2011 berkisar antara $\mathrm{Rp} 25.000-\mathrm{Rp}$ 30.000 per kg dan sekarang harganya berkisar Rp 10.000 - Rp 15.000 per $\mathrm{kg}$. Menurut Penelitian yang dilakukan Subiatho (2016), harga dan penerimaan petani buah naga terus mengalami penurunan. Penerimaan yang diperoleh petani per tahun dalam luasan lahan $1 \mathrm{Ha}$ dengan jumlah bibit 4000 batang dan 1333 tiang panjat yang tebuat dari kayu ulin, pada tahun 2011 penerimaannya sebesar Rp 147.960.000 dan tahun 2015 turun menjadi Rp 59.055.000. Hal tersebut terjadi karena banyak yang membudidayakan dan belum ada pengolahan lanjutan. Selain itu buah naga yang dipasarkan atau dijual di Kalimantan Selatan, tidak hanya berasal dari wilayah di Kalimantan Selatan, tetapi ada juga dipasok berasal dari Kalimantan Timur dengan harga yang lebih murah tetapi rasa yang berbeda.

Bila hal ini terjadi tentunya yang akan dirugikan adalah petani sehingga untuk mengatasi masalah ini pemerintah bersama-sama masyarakat dan perguruan tinggi perlu merancang strategi penanganan pasca panen buah naga yang tepat mulai dari hulu hingga hilir agar petani tidak dirugikan, yaitu selain dipasarkan dalam bentuk segar buah naga dapat diolah menjadi berbagai produk olahan antara lain sari buah, sirup, jam, dodol, stik, selai dan ice cream. Bahkan kulit buah naga yang beratnya sekitar 30 - $35 \%$ dari berat buah dengan warnanya yang merah dengan teknik-teknik tertentu dapat diolah menjadi minuman fungsional sumber antioksidan yang berguna bagi kesehatan serta dapat digunakan sebagai pewarna alami (Anonim, 2010).

Peluang usaha produk olahan buah naga masih terbuka lebar di daerah ini karena buah naga mempunyai beberapa kelebihan dibandingkan dengan buah-buahan yang lain, yaitu mempunyai khasiat yang bermanfaat bagi kesehatan manusia diantaranya 
sebagai penyeimbang kadar gula darah, pelindung kesehatan mulut, pencegah kanker usus, mengurangi kolesterol, pencegah pendarahan dan mengobati keluhan keputihan (Anonim, 2010) sehingga produk olahan buah naga dapat dijadikan sebagai pangan fungsional.

Permasalahan Mitra. Dari hasil observasi dilapangan didapatkan data bahwa :

1. Belum memiliki ketrampilan dan pengetahuan dalam meningkatkan nilai tambah berupa produk olahan buah naga.

2. Harga buah naga dan penerimaan petani yang terus menurun sedangkan jumlah petani yang membudidayakan semakin meningkat

3. Perlunya pengembangan inovasi guna keberlanjutan usaha dan meningkatkan pendapatan mereka.

4. Belum adanya modal usaha dan alat-alat yang memadai untuk membuat produk olahan pangan dari buah naga.

Melihat permasalahan tersebut yang dihadapi oleh mitra, maka perlu ditindaklanjuti dan diatasi melalui kegiatan ipteks ini. Berdasarkan analisis kebutuhan yang telah dilakukan dengan berdiskusi dengan kedua mitra dan mempertimbangkan kemampuan tim pelaksana Ipteks, maka permasalahan yang diprioritaskan untuk diatasi melalui kegiatan Ipteks ini adalah dengan memberikan pelatihan pengolahan hasil buah naga dengan membuat beberapa macan produk berbahan baku buah naga dan pelatihan manajemen usaha.

\section{PELAKSANAAN KEGIATAN}

Pelaksanaan kegiatan dilakukan secara terpisah di dua desa dengan mengambil tempat di Balai Desa masing-masing. Kegiatan dilaksanakan selama dua hari, dimulai dari kegiatan di Desa Kunyit dan dilanjutkan di Desa Tirta Jaya. Pelaksanaan masing-masing dimulai dengan acara perkenalan, ceramah tentang pentingnya usaha mandiri (kewirausahaan), kiat-kiat usaha dan memanfaatkan peluang yang ada, meningkatkan nilai tambah produk, dan sekilas tentang pemasaran. Selanjutnya praktik pengolahan hasil dari buah naga. 
Untuk memudahkan kegiatan praktik, peserta dibagi dalam kelompok kecil sesuai dengan ketersediaan alat yang disediakan. Sebelum praktik, terlebih dahulu diterangkan tentang bahan utama dan pendukung, alat yang diperlukan, dan cara pembuatannya. Selanjutnya masing-masing peserta diharuskan berperan aktif dalam setiap langkah atau proses pembuatan olahan buah naga, dimulai dari pembuatan stik buah naga, selai buah naga, dan es krim dari buah naga.

Setiap macam olahan diulang dua kali dan tiap ulangan dibiarkan peserta masing-masing bekerja dan berkreasi sesuai keinginan masing-masing, kecuali untuk olahan es krim, karena memerlukan proses yang lebih lama dan memerlukan peralatan khusus sehingga tidak dilakukan pengulangan. Selesai satu macam olahan langsung disambung dengan olahan lainnya, sementara hasil olahan yang telah matang disuguhi kepada semua peserta untuk dicicipi rasanya.

\section{HASIL DAN LUARAN}

Berdasarkan hasil uji visual, ternyata hasil olahan buah naga sangat menarik dari segi warna dan rasanya juga disukai oleh semua peserta sehingga membangkitkan minat untuk mencoba, dan dapat dijadikan sebagai salah satu peluang usaha untuk menambah pendapatan keluarga.

Hasil pemantauan di lapangan setelah \pm 15 hari setelah pelatihan, ternyata dari Desa Kunyit sudah ada yang mengusahakan membuat olahan stik dan telah memperoleh order untuk hajatan perkawinan pada tanggal 8 September 2017, ini memberikan semangat bagi yang mengusahakannya (Ibu Sri Yulianti) untuk terus berkreasi dan berinovasi dalam mengembangkan usahanya. Peserta dari Desa Tirta Jaya berdasarkan hasil pemantauan sampai tanggal 24 Agustus 2017 baru di RT VIII yang sudah mengolah untuk acara PKK RT, namun secara komersial masih belum terpantau secara nyata.

Pengembangan olahan buah naga di kedua desa sampai saat ini masih terkendala mahalnya harga buah naga akibat masa paceklik dan rusaknya kebun buah naga akibat virus yang sampai saat ini belum mampu ditanggulangi, bahkan banyak pekebun atau pengusaha buah naga yang merugi. Sebagai pengganti 
kelangkaan buah naga dengan harga menguntungkan sebagai bahan baku olahan, pelaksana IbM menyarankan agar untuk sementara dilakukan inovasi menggunakan buah-buahan lain yang tersedia seperti nenas, nangka, mangga, dan lain-lain asalkan hasil olahan masih mampu menutupi biaya produksi, meskipun sdah agak menyimpang dari tujuan awal diselenggarakannya program IbM ini. Hal ini masih memungkinkan, karna berdasarkan hasil evaluasi, program IbM pengolahan buah naga ini mampu memberikan luaran berupa:

1. Meningkatnya pengetahuan dan keterampilan peserta didik, terutama dalam hal pengolahan hasil buah naga dan sejenisnya

2. Meningkatnya kemampuan manajerial dan menciptakan peluang usaha

\section{KESIMPULAN}

1. Buah naga dapat diolah menjadi berbagai produk olahan dengan menggunakan teknologi yang sederhana, dan dapat dilakukan sebagai industri rumah tangga.
2. Berdasarkan tingkat penerimaan konsumen, olahan buah naga sangat disukai karena rasa enak, renyah dan gurih, warnanya menarik dengan aroma yang khas.

3. Dapat dijadikan salah satu peluang usaha

4. Pengabdian masyarakat (IbM) ini mampu memjadi motivasi dan mendorong jiwa kewirausahaan.

\section{Saran}

1. Perlu pendampingan yang terusmenerus dan ikut serta mencari peluang pasar.

2. Perlu mencari altrnatif pengganti buah naga sebagai bahan baku yag mampu memberikan keuntungan.

\section{DAFTAR PUSTAKA}

Anonim. 2010. Khasiat Buah Naga.

www.buahnaga.net/khasiat_b uah-naga/. Diakses tanggal 29 Maret 2017

Kristanto, D. 2008. Buah Naga Pembudidayaan di Pot dan di Kebun. Penebar Swadaya. Jakarta 